\title{
8
}

\section{Stingy Egalitarianism: Precarity and Jealousy at the Sisiak Settlement, Madang, Papua New Guinea}

\author{
Deborah Gewertz and Frederick Errington
}

Martha Macintyre and Nick Bainton have described a Papua New Guinea (PNG) goldmine at Lihir that delivered such extraordinary affluence to landowners that they could become over-the-top makers and shakersthey could 'have it all' by staging remarkably elaborate customary rituals and by buying coveted four-wheel-drive vehicles. In this way, they were able to excel within traditional and modernist socioeconomies. In contrast to the past, in which 'exchange functioned as a levelling device, providing an important avenue for dispersing wealth and resources' (Bainton \& Macintyre, 2016, p. 121), the flood of incoming money allowed a multiplicity of ceremonial distributions without significant depletion of resources. Indeed, the 'resulting efflorescence of custom has been a defining feature of their engagement with mining capitalism' (Bainton \& Macintyre, 2016, p. 110). For those cash-fortunate Lihirians, theirs was a 'new world of surplus' (Bainton \& Macintyre, 2016, p. 111). They had won big-time, and the mine handouts appeared endless.

For those less well-placed Lihirians (those who were not owners of mining land), the benefits of mining capitalism have been elusive. Certainly, some were given start-up money for small businesses, so as not to be entirely excluded from mine-based prosperity. Yet, their various enterprises 
frequently failed, and no further financing was offered. When their hopes 'for perpetual financing were foiled', these would-be entrepreneurs retaliated by 'allowing all the chickens to die, smashing the can crusher and letting several hectares of vegetables to rot in the ground' (Bainton \& Macintyre, 2013, p. 156). As manifestations of what Macintyre and Bainton characterised as 'ferocious egalitarianism', these dramatic actions have 'less to do with the morality of distribution or social equality, and are more related to the feeling among certain individuals and groups that they have been slighted or have missed out on their just entitlement' (Bainton \& Macintyre, 2016, p. 156; see also Bainton, this volume). The ferocity was a 'levelling' reminiscent of the 'negative agency' enacted by Huli women, living elsewhere in PNG. Feeling insufficiently appreciated for their productive and reproductive services, these women 'jump the fence', abandoning their homes and gardens and surviving largely through prostitution (Wardlow, 2006). Disappointed Lihirians, as with the Huli women, were asserting their efficacy. They were saying, in essence, 'fuck you'- 'if you don't value me, I'll bring the house down'.

Our most recent work, among the Chambri at Sisiak settlement (outside Madang), provided an instructive contrast to the Lihirian case. If the Lihirians have won big and lost big, the Sisiak Chambri have simply lost out. If the Lihirians manifested Melanesian social life on steroids, the Chambri manifested Melanesian social life on life support. Rather than exhibiting ferocious egalitarianism, they exhibited 'stingy egalitarianism'. Clearly, this type of egalitarianism was intended to 'level'. The levelling was neither a product of an expansive 'giving it all away' nor a dramatic 'bringing the house down'. Instead, these Chambri engaged in a pre-emptive refusal to let anyone get ahead. However, as we shall see, for Lihirians and Chambri, the (largely) outside forces of global capitalism have, for better or worse, called the shots.

Thus, we offer our chapter as a complement to Macintyre and Bainton's fascinating study - as a (somewhat dark) contribution to an inventory of Melanesian social lives and concomitant egalitarianisms, as they emerge and transform in relationship to capitalism. 


\section{On Aspiration and Precarity}

Our thoughts about social change in the Western Pacific have engaged Marshall Sahlins' distinction between 'developman' and 'development'. Although prompted by the encroaching Western capitalist economy, these modes of change differ in their historical trajectories. Developman can be a lengthy process in which people innovate with novel resources to become more of who they already are-where new wine gushes from old bottles, as contenders court allies and confound adversaries during increasingly intensified social and ritual events. Development is a modernist process in which people strive with novel resources to become other than who they already are. It is a process wherein 'each person takes the betterment of himself as his life project' (Sahlins, 1992, p. 13). If developman does shift into development, Sahlins argued, it is prompted by 'humiliation'-when the new wine, once embraced by the gallon, is understood as low-status swill. ${ }^{1}$ That said, without necessarily discounting humiliation as an impetus for change, our PNG research indicates that people, particularly the young, may embrace a modernist process for a number of reasons. Principally among these may be the desire to escape the increasing demands of an elaborate system of developman. There is another possibility, as outlined above for those Lihirians made rich by the mine-a synthesis between developman and development, between the customary and the modernist. As Macintyre and Bainton showed regarding Lihir, people may want to become more of who they already are and to become different from what they are. ${ }^{2}$ They may aspire to have the best of both worlds. ${ }^{3}$

For the Chambri living at Sisiak, aspirations were generally quite modest: for the most part, just to get by. For them, like those urban Papua New Guineans described by Sharp, Cox, Spark, Lusby and Rooney (and, again, unlike the revenue-rich Lihirians), their lives were constrained by 'precarity'- by unpredictability and insecurity' (Sharp et al., 2015, p. 2). It must be noted that much of the literature concerning precarity comes from political science and positions precarious workers in a post-Fordist, neoliberal labour market. Considerations may include whether the

\footnotetext{
1 For more detail on 'humiliation' in Melanesia, see the essays in Robbins and Wardlow (2005).

2 See also Errington and Gewertz (2005, pp. 163-170) for a demonstration that development can be embraced without humiliation negating the aspirations of developman.

3 In this sense, to use Keir Martin's (2013) phrasing in his analysis of contemporary Tolai, they wished to be both 'big men' and 'big shots'.
} 
precarious constitute a class — the precariat—and, if so, whether this class has the 'consciousness' necessary for revolutionary potential. Therefore, it is perhaps possible 'to identify or imagine precarious, contingent or flexible workers as a new kind of political subject, replete with their own forms of political organisation and modes of expression' (Neilson \& Rossiter, 2008, p. 52). While the economically marginal at Sisiak have never known Fordist employment conditions and were not on the brink of class militancy, we nonetheless find the term 'precarity' useful in depicting their lives. After all, they have been affected by the same neoliberal policies that have caused massive insecurities worldwide. For instance, externally imposed 'structural adjustments'-beginning in PNG during 1994-have replaced an already minimal safety net with user-pay practices. This, in combination with PNG's commitment to a national economy based on capital-intensive resource extraction, including that of the Lihir goldmine, has left many local peoples hard-pressed and their economies stagnant.

The fact that those at Sisiak were hard-pressed-that their lives were precarious - has resulted in a widespread inability to achieve either developman or development. This inability, in turn, came to inflect a broadly Papua New Guinean expression of still-uncolonised consciousness-a persisting ethos of competitive egalitarianism. ${ }^{4}$ Sisiak males, principally, would feel diminished by, and jealous of, any successes of another; at the same time, they generally lacked the material resources to push back directly. As John Taylor found in urban Vanuatu, most at Sisiak lacked both 'distributive' and 'possessive' agency (2015, p. 42). Consequently, because most did not have material efficacy, the few who did (the 'tall poppies') became targets of jealousy; correspondingly, the attack - the 'getting even'-took devious forms. Jealousy prompted revenge through sorcery, and the resulting complex became a compelling social fact within settlement life. ${ }^{5}$

4 Here, we reference Jean and John Comaroffs (1991) analysis of Christianity and its colonisation of the consciousness of indigenous South Africans.

5 Other scholars of Pacific societies have, of course, discussed sorcery. See, for example, Tonkinson (1981), Knauft (1985), Forsyth and Eves (2015), Kirsch (2006), Rio (2010) and Taylor (2015). Indeed, Chambri have long been concerned with sorcery. However, our focus here is not on sorcery per se, but rather on the jealousy under conditions of capitalist precarity that triggered sorcery fears (and perhaps practices) at Sisiak. That said, not all contemporary sorcery practices must be tied to capitalism, as Herriman (2015) has shown concerning Java. Moreover, unlike in parts of Africa, the precarity of Chambri life at Sisiak has not generated much speculation that capitalism was a mysterious process, one ramifying into an economy of the occult. On the latter, see Comaroff and Comaroff (2001) and Smith and Mwadime (2015). 
Moreover, to the extent that this jealousy/sorcery complex was considered justified, at least by the perpetrator, it became part of the moral economy. ${ }^{6}$ As James Carrier pointed out, the 'morality' of the 'moral economy' stems from material transactions reflecting-building on, looping back onsocial obligations (Carrier, 2017; see also Bainton; Cox, this volume). This has been certainly true in Melanesia, where the value of transactions frequently lay in their sociality. Further, in the context of development, commodity transactions might have a 'gifty' aspect. ${ }^{7}$ Accordingly, many settlers at Sisiak were jealous, not only of the (seemingly unwarranted) material success of others, but of the relationships that accompanied the success. ${ }^{8}$ Among these resource-poor Papua New Guineans, the result was a multiple and moralistic levelling - one that coerced the prudent to keep their heads down (cf. Oppermann, 2016).

The tensions underlying everyday life at Sisiak were familiar to us from past work among rural and urban Chambri; yet, they were to flare up alarmingly when we joined a local household. Our money made just some lives notably less precarious; the affluence we bestowed aroused contention. Our presence provided 'unique opportunities for individuals to "rise above" others ... [creating] a high degree of risk particularly as it ... attract[ed] the jealousy of others' (Taylor, 2015, p. 42).

\section{On the Chambri at Sisiak}

Sisiak began as an official settlement of Madang in 1969, when the colonial administration purchased 220 acres of land near the native village of Sisiak to settle migrants. (For a brief history, see Gesch, 2017, p. 109.) These were employed in rebuilding, expanding or otherwise developing

6 Oppermann, writing about Buka, another Papua New Guinean group, suggested that sorcery is 'imagined as the anarchy of jealousies' (2016, p. 186). More specifically, he found that elites 'fear that it is "uneducated youth" and others jealous of their success that both spread rumours of sorcery and practice it ... [T] he discourse of poisen can thus operate as a levelling critique of elites' (2016, p. 195). Comparably, Schwoerer reported, concerning the Eastern Highlands of PNG, that 'sorcery accusations are the result of uneven economic development and failure to deliver basic social services' (2017, p. 317). Additionally, see Maggio (2018) on sorcery accusations calibrating a moral economy within an urban settlement in the Solomon Islands.

7 James Carrier (2017) referenced his ongoing relationships with the proprietor and staff of his neighbourhood shop in Edinburgh.

8 As our colleague, Dr Bryant Allen, described in an email received on 15 July 2018: 'no chiefs in Melanesia. Most men feel they are as good as the next man. So, when one prospers and another does not, what can be the reason? It is either a personal failing or the other has some supernatural assistance, either to succeed, or to sabotage your success.' 
the coastal town, whose strategic port was heavily damaged during World War II (see Sinclair, 2006, p. 258). Most of the labourers were drawn from villages proximate to the Sepik River or other lowland areas, from groups in which men competed for hard-won, if transitory, eminence. ${ }^{9}$

Chambri people, with whom we have long worked (Deborah since 1974 and Fred since 1983), comprised one of these egalitarian sociocultural groups. ${ }^{10}$ By the 1970s, Chambri residing in their home villages on Chambri Island were engaged in developman-again, a process through which social and cultural innovation enabled people to become more of, and better at, what they already were. Senior men eagerly augmented their power through the appropriation of new opportunities in the form of cash and commodities. They pressured at least one of their sons to obtain an education and a well-paying job. Remittances, it was hoped, would enhance patriclan prestige and continuity by enabling bigger and better brideprices. By 1983, a sufficiently large cash brideprice was paid that the groom's father bragged that his clan could kill the bride, for her death compensation had already been given.

By 1987, that which allowed clan leaders to conceive of becoming more of what they already were was allowing their sons to conceive of becoming less of what their fathers wanted them to be. These sons insisted that they were 'young lives' and exercised their choices and decisions so as to participate in a system premised on personal choice: one that conjoined freedom of religious choice, freedom of commodity choice and freedom of marital choice. ${ }^{11}$ Thus, they embraced development, whereby social and cultural innovation occurred such that people became 'modernist'-more and better at what they had not been. Often seeking new opportunities in town, they moved to urban settlements. Many moved to Chambri Camp in the town of Wewak. There, the road connection to the Sepik River made circular migration relatively easy and frequent. Women from

9 A comprehensive urban study of Madang indicated that the Sisiak programme has been specifically oriented towards the Sepiks' (Russell D. Taylor \& Partners Pty Ltd, 1972, p. 23).

10 This is not to dispute the presence of hierarchical relationships between men and women.

11 The choices and decisions exercised by these young men were explicitly directed towards participating in another system, one that had been building since a variety of late nineteenth- and early twentieth-century 'first contacts' and becoming increasingly pervasive after Independence in 1975. They were self-styled 'young challengers', to use Pierre Bourdieu's term, who were struggling against orthodoxy to make their own choices and decisions — struggling to make 'their [own] mark ([or] 'epoch')' (Bourdieu, 1983, p. 60). This would not be possible 'without pushing into the past those who [had] an interest in stopping the clock, eternalising the present stage of things' (Bourdieu, 1983, p. 60). 
the Chambri villages would occasionally bring smoked fish for sale at the market and as gifts for town-dwelling kin. Town dwellers would readily visit home villages for holidays and ritual events like funerals.

In contrast, in the absence of a road link from Madang to the Sepik River, those at Sisiak had only limited access to the people and resources of the home villages. Unfortunately, the period of post-war prosperity, which had encouraged many to migrate to Madang, proved to be of only limited duration. To some extent, Madang's current circumstances reflected the general shift in the PNG economy-an economy, as mentioned previously, that was increasingly focused on resource extraction at limited sites, leaving coastal towns with diminished economic opportunities. This was evident in our Sisiak data.

By 2018, Chambri at Sisiak were struggling to get by, significantly more so than Chambri elsewhere. According to the tenants' list constructed by Michael Kosai, our assistant and Sisiak resident, there were 54 houses at Sisiak inhabited by Chambri-identified people; these included 100 adults -73 Chambri and 27 non-Chambri affines. ${ }^{12}$ (It should be noted that Kosai's list excluded children, some of whom were in their twenties, as well as elderly 'dependents'. Please note that we use Kosai's terms throughout.) For those operating within the informal economy, 41 were craftsmen, earning money by selling carvings, stencilled clothing, baskets, woven bracelets and shell jewellery to other Papua New Guineans and to the relatively few Western tourists still coming to Madang. ${ }^{13}$ Some of these also sold betel nuts and cigarettes outside their houses. Although sales were variable and no records were kept, they claimed a fortnightly income of between PGK 20-200, with an average of PGK 51 for these two weeks. (As of 13 July 2018, shortly after receiving Kosai's data, PGK 1 = USD 0.33.)

Another 10 people were peddlers and resold small items, ranging from batteries to instant noodles. Their sales were comparably variable and unrecorded; however, they reported a fortnightly income of PGK 50-150, with an average of PGK 71. Others were similarly self-employed. One was a farmer, growing vegetables to sell at Madang's

12 All Chambri names are pseudonyms.

13 Tourism to PNG has dramatically declined in recent years. This has, in part, been due to the economic downturn of 2008 and to PNG's reputation as a dangerous place. Although some young backpackers did visit, most of the moneyed tourists arrived during sporadic visits by cruise ships, disembarking only for brief and highly regulated excursions. 
main market, with a fortnightly income of PGK 200. One was a lay clergyman, whose congregation provided him with a fortnightly income of PGK 100. Three were businessmen who used their vehicles to transport passengers and goods. They earned an average fortnightly income of PGK 470. One was a consultant who sold business advice. His fortnightly income was PGK 500. Three were hired hands, with average fortnightly incomes of PGK 107. Two were seamstresses, with average fortnightly incomes of PGK 140 . One was a housecleaner with a fortnightly income of PGK 170.

Within the more formal economy, three worked in factories, with an average fortnightly salary of PGK 325 . Two worked for mining companies, with an average fortnightly salary of PGK 763 . Four were carpenters, with an average fortnightly salary of PGK 318 . One worked for the village court, with a fortnightly salary of PGK 150 . One was a seaman, with a fortnightly salary of PGK 700. One worked as a counsellor for the local government, with a fortnightly salary of PGK 300. Three were teachers, with an average fortnightly salary of PGK 477. One worked as Madang's Commissioner of Boy Scouts, with a fortnightly salary of PGK 250. Two were security guards, with an average fortnightly salary of PGK 385. One was a mechanic, with a fortnightly salary of PGK 510. One was an electrician, with a fortnightly salary of PGK 276 . One was a secretary, with a fortnightly salary of PGK 430 . One was a store clerk, with a fortnightly salary of PGK 276 . One drove a van, with a fortnightly salary of PGK 250.

It should be emphasised that income earned in the informal economy through market sales, as with craft items, was likely to be erratic. In the more formal economy, the range of pay varied from PGK 800 for a mineworker to PGK 350 for a factory worker. Some factory workers, who had to pay for their own transportation and, sometimes, uniforms, told us that it was hardly worth it. On the other hand, unmarried children in their twenties (who were not part of Kosai's survey) might well have contributed minor sums (perhaps through the sale of crafts) to family income. Many with a fortnightly salary attempted to supplement their incomes by selling crafts and, in a few cases, food (e.g. via buns purchased from a local bakery and resold). Finally, it was possible that money came in through illegal means, as with the sale of drugs, alcohol, sex and stolen items. 
Overall, Sisiak's two-adult households, in which at least one Chambri was resident, earned approximately PGK 15,116 per fortnight, averaging PGK 151.12 per adult-the equivalent of USD 48.37 or approximately USD 97 per two-adult household. Of the combined adult income of some PGK 300 per fortnight, Chambri households spent the following on semiobligatory purchases: PGK 20 on transportation to work and the market; PGK 20 on water; PGK 20 on electricity; PGK 60 on school fees and other children's needs; and PGK 40 on miscellaneous items (including betel nut). There was, as well, a limited amount of money available for food. This averaged PGK 140 (USD 46.20), which did not buy much during a two-week period. Food purchases tended to be basic and minimal: PGK 100 at the stores was primarily spent on rice, instant noodles, canned fish and meat, PNG-produced sausage, hard biscuits, bouillon cubes, small amounts of oil, tea, sugar, powdered milk and, occasionally, butter and eggs. PGK 40 at the town market was spent mostly on garden vegetables. Fresh meat would be a treat. Crucially, in our experience, many residents at Sisiak were frequently hungry.

We had known for some time that hunger was a chronic problem at Sisiak. In 2006, for example, we wrote about our old friend, Paul Kamboi, who was finding life in the settlement difficult. A former 'young life', he had fled to Sisiak to escape ensorcellment by senior Chambri men, who had chosen a different woman for him than the one he wished to marry. ${ }^{14}$ Never returning to Chambri Island, he worked for a timber company. After it closed in the 1980s, he supported his family by selling carvings to tourists at the market. Sales were only occasional; sometimes, he could not afford the bus fare home and had to walk the long way back to Sisiak in the scorching tropical sun. Nor could he really afford the tuition for his younger son's education. Worst of all, he and his children sometimes had to go without food. While he did enjoy chatting with his mostly Chambri neighbours at Sisiak, he was often distracted by hunger. And, he could not let this be known, lest he be perceived as making a request of others, who were probably as short of food as he was. Correspondingly, Paul had to tell his youngest child, (then) 10-year-old John, that he was a big boy now- too old to cry if he was hungry.

14 For more detail about the prescribed Chambri system of mother's brother's daughter's marriage, see Fortune (1933) and Errington and Gewertz (1987, p. 50). 
During 2011 and 2015, we visited Paul briefly; however, it was not until 2018, when Paul was 62, that we spent appreciable time with him. He had been diagnosed with prostate cancer, and we had been sending him money to pay for medical costs and John's school fees. In response to his invitation, we moved in with him at Sisiak. His area consisted of his house, several outbuildings, a shower enclosure and an outhouse, all demarcated from the narrow, unpaved road and from neighbouring areas by carefully tended ornamental bushes. We were given two rooms in his house, displacing his two unmarried daughters, Faith and Alberta, and their young children. They moved into an outbuilding, where John ordinarily slept by himself. On occasion, David (Paul's divorced, older son) resided in one of the outbuildings. Other active participants in the household lived nearby and visited daily — these were Paul's eldest daughter (Pauline), her Chambri husband (Peter) and their three children.

In urging us to join him, Paul was obviously pleased that we could pay for the electricity to be turned on and for his overdue water bill to be covered. He was also anxious; he was unsure how his Sisiak neighbours would react to our daily presence. Indeed, as we were to discover, of all those Chambri we knew at Sisiak - many for over 40 years-Paul was virtually the only one willing to take responsibility for us. The others were concerned that we, as affluent white people- the lone white people, they told us, ever to live at Sisiak-would bring trouble. Certainly, trouble might come from other Chambri. Moreover, Sisiak was a 'mixed' community of migrants from a variety of linguistic and cultural groups; most were Sepiks, but many were unentailed to Chambri. Criminally inclined youth, either in small groups or in larger gangs, were regularly (extremely) intoxicated with locally distilled spirits and marijuana. They were known to burgle houses and assault occupants. At the very least, these youths 'heeded the authority of no one' and 'disturbed everyone' as they roamed up and down the narrow roads, their loud music and boisterous shouts lasting throughout most nights. Their conspicuous good times as (later-day) 'young lives' kept the rest of us awake in intimidated silence. To protect us from actual incursion, Paul arranged for 'security'. He enlisted the help of his now 22-year-old (and somewhat alienated) son, John, to keep his fellow gang members-again, Sepiks from a number of groups-at arm's length. Despite this logic, the plan backfired. 
Our arrival at Sisiak was noticed. Neighbours stood by as we unloaded a heavy suitcase and bulky, if basic, items such as foam mattresses, pillows, bedding, mosquito nets and cooking utensils, plus luxury items as a fan and a sturdy kerosene stove. Finally, we unloaded freshly purchased household provisions, including a $10 \mathrm{~kg}$ bag of rice. Previously in PNG, we had cooked for ourselves and shared with others. This time we provided money for food and Paul's daughters shopped and cooked for us. Consequently, everyone had plenty to eat, even if it was mostly rice augmented with instant noodles, canned fish and market vegetables. Everyone had more energy and visibly put on weight. And, Paul was less discomfited by his illness.

Much as during our previous stints living in Chambri Camp in Wewak (as recently as 2015), things seemed to be working out well enough at Sisiak. Even though we were frequently kept awake by the raucous youth, their activities remained outside our immediate household area. Faith and Alberta, and sometimes Pauline and Peter, went daily to the town market to sell their handicrafts. On returning, they reported how the market had been for them. A 'good market' was earning PGK 10-15 through the sale of a stencilled t-shirt. This said, there were many market visits for which transportation costs (a round trip cost of PGK 2 per person) were not met, as nothing was sold. Before we arrived, the family would have simply gone to bed hungry. Subsistence had been largely hand-to-mouth, as remained the case for many Sisiak residents. ${ }^{15}$

Given the prevalence of these straitened circumstances, the lift in their fortunes was a source not only of gratification but of concern to Paul and his family. Others might easily become 'jealous' (jelus). ${ }^{16}$ It was best that we white people not sit or, especially, eat on the porch, lest those passing by be reminded of our presence in this household. It was better that we all ate in darkness or, at the very least, inconspicuously (in fact,

15 Some limited food sharing did occur, particularly among proximate neighbours, if a family happened to have a minor windfall.

16 Francis Mihalic, author of the classic Jacaranda dictionary and grammar of Melanesian Pidgin (1971), does not list 'jelus' as a Pidgin entry. As a synonym for the English word 'jealous', he lists 'ai tudak', which literally means 'He is blind. He is jealous' (1971, p. 58). The implication is of someone who is blind with jealousy. The other provided synonym for 'jealousy' is 'mangal (1971, p. 129), attributed to speakers in New Hanover. This means 'to covet, to long for, envy, yearn for, desire strongly' (1971, p. 129). It may be that the concept of jealousy has become more directly invoked and is no longer metaphorically related to blindness. Additionally, it has become more universalistic - no longer tied to an obscure regional language. Further, its meaning has, perhaps, expanded from merely coveting to actively resenting. 
most Chambri did eat indoors, circled around a little lamp). Despite these precautions, Paul's family soon became aware of jealous gossip from Chambri and others. ${ }^{17}$ It was rumoured that, with these white people there, Paul's family could now 'eat meat every day', could eat fresh (not canned) beef, chicken, mutton or pork. ${ }^{18}$ In fact, most of our meals featured canned fish or beef; sometimes, we did splurge. Undoubtedly, the live chicken that Faith and Alberta carried home from the market one afternoon was noted by the community. ${ }^{19}$

Further, John, influenced by his fellow gang members, made it clear that he did not want our help in continuing his education. Recently, we had sent money to pay for 'top-up' courses so that he might improve his grades and progress in school. His friends demanded to know why he should receive special help from us while they, whose scores had been as bad as his, did not have white people sponsoring them. Paul became alarmed that these friends, and possibly others (Chambri and non-Chambri), were jealous of his relationship with us. He began a disquisition on jealousy and the sorcery that it prompted. At Sisiak, anyone and everyone might feel jealous and be thought capable of enacting sorcery. ${ }^{20}$ Both of these fostered the moral economy of levelling.

\section{On Jealousy, Sorcery and the Moral Economy}

As part of Paul's disquisition, he brought out a notebook containing information that he wished to possess in consultable form. It contained the names of totemically significant rocks on Chambri Island-these were names that his sons should have learned if they had been initiated.

17 Taylor quoted an informant saying that, 'in town, all we eat is money. Town isn't safe because it is too mixed. There is too much mixing of people from different places and too much mixing of kastom. There is also too much jealousy' (2015, p. 43).

18 Lamb flaps (sheep bellies), once eaten by many Papua New Guineans, have become a treat, largely displaced by locally produced sausage. On lamb flaps, see Gewertz and Errington (2010).

19 For a differently inflected set of relationships linking jealousy, sorcery, white men, money, and food under urban circumstances in PNG, see Bashkow (2006, pp. 134-144).

20 The social role of sorcerer had once been part of the persona of knowledgeable men on Chambri Island, including during the florescence of the developman economy. At Sisiak, the role had become much more generalised, and it was unclear who the practitioner might be and, much less, who might have enlisted the practitioner's help. Moreover, although the Chambri did have techniques of sorcery detection, these never resulted in a clearly identifiable culprit against whom definitive action could be taken. In this latter regard, they were unlike the Gebusi described by Knauft (1985). 
It contained the birth dates of all his children and grandchildren. Finally, it contained the names of those living throughout the mixed community at Sisiak from whom he sensed some grudge-these were people that he and his children should avoid to forestall possible sorcery. Despite his precautions, his daughter, Faith, had already encountered jealousy. She was singled out by her teachers due to her academic success and encouraged to progress to high school; however, Paul had insisted that she drop out lest sorcery ensue. Undoubtedly, some had been jealous of him and his family for the help Deborah had given over the years.

Paul continued with the suggestion that his stepbrother, Jacob, had undoubtedly been killed by sorcery that had emanated from jealousy. Like Paul, Jacob had worked closely with Deborah since her first fieldwork stint on Chambri Island, which began in 1974. By 1987, he had begun to call himself a 'traditional anthropologist'. His various (self-designed) projects included seeking analogues between 'traditional' Chambri stories and the Bible. ${ }^{21}$ Additionally, after he had settled relatively permanently at Chambri Camp in Wewak, he became preoccupied with soccer. Eventually rising to the rank of a 'Level Three Soccer Referee', he presided over matches with verve augmented by his official Fox 40 soccer referee whistle-a gift from 'the coach of America', the soccer coach at Deborah's university.

Jacob died in 2007. It was not until 2014 that we were able to visit his widow who, following his last instructions, unlocked for us the box containing his papers and memorabilia. Inside, we found hundreds of hand-written pages. There were accounts of debts owed to, and incurred by, him. There were lists of secret names and ritual prerogatives possessed by his clan. There was a carefully drawn family tree that depicted his descendants from his sequence of three wives. There were traditional Chambri stories, perhaps ultimately intended for us. There were originals of letters that had been faxed to various business interests and politicians (including several prime ministers), requesting sponsorship of his activities as a traditional anthropologist. There were descriptions of soccer matches. There were accounts of wrongs against him and, sometimes, others in his family (including a 17-page account of an assault on a daughter), all written to claim compensation if not legal redress. There were documents of infractions he witnessed as an auxiliary policeman, as when

21 See Gewertz and Errington (1991, pp. 154-168). 
several youths taunted a woman by cutting down her flowers. We were unsurprised that, in pursuing his urban opportunities, he had become an auxiliary policeman.

Finally, as he lay dying of what was formally diagnosed as mouth cancer, he listed those whose grudges against him might have prompted the sorcery that, he was certain, was killing him. Principal contenders were a mixed group of those with traditional and more modernist grievances: those he had charged in the assault on his daughter; one or more of his jealous former wives, each striking out at the others through him, and, most likely, fellow soccer referees envious of his successes. Of the latter group, he surmised that a specific Chambri referee was the assailant.

Paul, in recounting the circumstances of Jacob's death, was certain that he had been killed by the other Chambri referee. For our part, we observed sadly that, of his various endeavours, Jacob was most proud of his accomplishments as a referee. Paul agreed and, with some bitterness, talked of the 'negative thoughts of jealousy' that led to sorcery, with the end result that everyone was brought 'down to the same level'. ${ }^{22} \mathrm{He}$ then announced that our continuing presence was making him and his family uncomfortably conspicuous and putting them at risk; it was best that we leave within a week—we agreed.

The following night was again sleepless. Emerging at dawn, we found that the household was already up and vigilant. Faith and Alberta stood outside, looking warily at the road where the revellers remained active. As Fred walked onto the porch, Paul immediately pushed him back inside, stating most emphatically, 'they must not see you; do not show yourself. It is no longer safe for you to stay. You must leave immediately'. We were soon to discover that John, during the night, had taken a brief leave from fellow gang members. So drunk that he could barely stand, he had demanded money from Paul to buy more alcohol and had threatened his older brother, David, with a gun. ${ }^{23}$

Agreeing with Paul that our continued presence endangered ourselves and our hosts (John being the exception), we threw our things together. With transport quickly arranged, we departed later that morning for a hotel in town. Subsequent to our departure, perturbations continued. Two of our research assistants were menaced with knives by gang members seeking

22 For a moving account of frustrated ambition caused by sorcery, see Smith and Mwadime (2015).

23 For a discussion of the salience in PNG of the image of the drunken and/or stoned young man with a gun, see Macintyre (2008). 
money. Then, the night after our departure, members of John's gang left the road and entered Paul's immediate area to obtain the money they assumed that we had left with him. After David, in response to this act of trespass and household intimidation, ordered them out, John again threatened him—-this time with a knife. ${ }^{24}$

In conclusion, our presence had become a major disruption in an ongoing moral economy, one in which Sisiak residents were alert to the accomplishments of others. This was especially the case if those accomplishments could be construed as resting on advantageous relationships. The jealous did not feel that they lacked ability or virtue; instead, they felt that they had been unfairly excluded from the relationships benefiting others - that they had been unfairly diminished by the enabled eminence of others. In this sense, by striking back at the (undeserved) advantages we had provided, sorcery and violence perpetrated by youths (at least as a possibility) served as a mode of moral re-equilibration. ${ }^{25}$

\section{On Levelling among the Economically Precarious}

By 2018, few at Sisiak had either the means or the inclination to stand out. The extravagance and flamboyance of a wide range of ceremonies we had witnessed on Chambri Island had (as far as we know) never been a part of Sisiak life. These were ceremonies in which 'big men' mobilised their followers, arranged for the playing of sacred flutes to summon ancestral presences, and 'strutted their stuff. Instead, at Sisiak, 'traditional' ceremonies were primarily limited to occasions of mourning; these had become culturally generic and modest-in this regard, the contrast with Lihir could not be sharper. One mourning ceremony that we witnessed in 2011, although well attended by the deceased woman's Chambri and non-Chambri family, friends and neighbours, was minimally financed through PGK 20 contributions from her children and grandchildren. The 'thanks' to those attending-instant noodles, garden vegetables and portions of lamb flaps-were limited and laid out with the utmost care to ensure that everyone received exactly the same amount.

24 We and Sisiak residents were fortunate that no one was actually injured due to our stay. In this regard, our circumstances were quite unlike the tragic ones related by Don Kulick (1991).

25 Although sorcery and physical violence operate in different ways, they can be used in concert. See Cox and Phillips (2015) for an elaboration. 
Moreover, and relatedly, in response to our inquiries - in conversation and a questionnaire-we were to discover that what it meant to be a Chambri at Sisiak had become truncated. Neo-Melanesian (Tok Pisin), rather than Chambri, was the language of everyday life within families and between others, whether Chambri or non-Chambri. Many Chambri at Sisiak did not speak any Chambri at all. Aside from those of Paul's generation, few had ever visited the home villages for more than a week or so. Nevertheless, just having a Chambri father was usually enough to make one a Chambri.

This said, there was a sense that a Chambri should know, or at least value, Chambri things. Certainly, some (including those who did not speak the Chambri language) mentioned that being a Chambri was to be heir to a distinctive language, one strikingly different from those spoken in neighbouring Sepik River villages. ${ }^{26}$ And, there were still senior men, including Paul, who were not only fluent Chambri speakers, but also (because they had been initiated) possessed impressive cosmological knowledge. For instance, in reminiscing with us, Paul recounted with pride the stories about the creation of Chambri as a place of ancestral power. These stories included restricted knowledge conveyed to initiated men and everyday knowledge literally conveyed at a mother's knee. Among Paul's pleasant childhood memories was that, after supper on Chambri Island, his mother would tell him and his sister traditional stories. In response to our direct question about social reproduction, he regretted that his kids knew nothing about Chambri Island and would not want to live there; hence, there was no point in trying to pass any of this information on to them.

In asking about what it was to be Chambri at Sisiak, we probed people's likes and dislikes of life there. Our questionnaire revealed virtual unanimity (among our 30 respondents). They welcomed the proximity to the town, with its hospital, schools, stores and market. Unsurprisingly, they wished there were more opportunities to earn money to access these urban resources. They thought they could get on well enough with most of their neighbours. However, they strongly disliked the behaviour of some of the young men, such as their periodical criminal activities and nightly carousing, including shouting obscenities and harassment.

We asked them if they ever planned to leave Sisiak. Some talked vaguely about buying a block of land somewhere and building a house where it would be 'more peaceful' than in town. Nevertheless, this was well

26 Iatmul, belonging to the Ndu language family, is spoken in these neighbouring Sepik River villages. The Chambri language belongs to the unrelated Nor Pondo language family. 
beyond the means of most. Very few wished to return to Chambri Island. Land there had become somewhat scarce; most at Sisiak had not fulfilled ritual obligations in the home villages for many years. Village people simply did not know them and would ask, resentfully, 'who are you and where have you been?' Perhaps the most adequate answer to this question would be to demonstrate success during their time of absence. Thus, one said he would like to return to Chambri and take his father's place, provided that he had accumulated enough money (e.g. by winning the lottery) to build a large, permanent-materials house. ${ }^{27}$ Another anticipated a welcome home once he was dead; by then, he hoped to have saved enough money (through the sale of carvings) for his children to buy a coffin and arrange its transport to Chambri for burial.

Life on Chambri Island did have some appeal; it was less cash-driven than life in town. Nonetheless, few at Sisiak had, and fewer wished to acquire, the skills necessary for village life. Women did not look forward to paddling a canoe, setting fishing nets, cutting firewood and smoking fish. Even if they were willing to learn, they anticipated derogatory comments about their competence from an elderly mother-in-law. Paul's daughter, Pauline, had received a sufficiently biting critique on her one visit to Chambri that she never wanted to go back. Finally, expecting a tepid welcome, many feared returning to Chambri Island. Chambri Island remained a place of ancestral power; therefore, resentments encountered there could be acted on. To the extent that those living on Chambri Island were in place, those visiting felt out of place, socially and cosmologically. ${ }^{28}$

27 Michael Kosai, our research assistant, estimated that approximately one-third of those Sepik people living at Sisiak believe in 'fast money schemes' (Cox, 2018) and have invested in the likes of Papalain, SP Can, Uvisitract, RD Tuna Condom Case and Blood Diamond. He also said that there are currently (as of 2019) no lottery games in Madang.

28 In earlier descriptions of the Chambri as they lived in their home villages, we wrote about their active totemic division of labour, with its mix of competition and cooperation. Living there, we were often awakened by booming slit-gong drums, calling men to converge in elaborate men's houses to debate, in archaic Chambri, about their ritual prerogatives. Displaying immense 'communicative competence ... the knowledge and ability to speak in socially appropriate ways' (Bauman, 1975, p. 293) - debaters would mingle dance and oration. They would allude to their secret totemic names and attendant special powers that ensured the vitality of their patriclans and their capacity to attract wives, made their rivals fearful, regulated their portion of the universe in its succession of seasonal changes and anchored them in a landscape of signification. Indeed, walking through Chambri Island with ritually knowledgeable senior men was a lesson in the identity between people and place. Pausing every 20 or 30 yards at a succession of rock monoliths, we would hear the (often esoteric) polysyllabic names of, for example, the ancestor who, taking the form of a python, had moored his canoe there as part of the process of bringing the island into being. For these guides, Chambri Island was not just their home-it was central to their being as Chambri. 
Given that most had little alternative other than to remain at Sisiak, with its ups and downs, what were their prospects. ${ }^{29}$ Chambri there did take pride in their creativity and resilience. Based on their cultural history as carvers of traditional ritual objects and elaborately decorated touristic items, they enjoyed visualising complex designs. Now that international tourism to PNG had significantly diminished, these designs appeared on stencilled t-shirts for sale to other Papua New Guineans. Most mornings, Chambri did go to town to take their chances at the market, sometimes joking about their role in the 'informal economy'. (Once, when a little naked boy at Sisiak stood behind a table occasionally used in vending betel nut, someone quipped that he, too, was engaging in the informal economy.)

They did think about ways to earn more money-to improve the quality of their houses and more easily pay for electricity, water, school fees and food. In addition to selling handicrafts, their plans included raising chickens for sale; buying a drum of kerosene and offering small amounts for sale; finding a better job than at the local fish processing plant, where their pay barely covered the expenses of getting to work; acquiring power tools to make employment as a carpenter more viable; creating an online presence for the sale of stencilled t-shirts and carvings; learning computer skills; or qualifying as teachers. In following these aspirations, they knew they would have to step carefully. For example, the woman who wished to sell chickens once had her chicks killed and was threatened at knifepoint by one of the local criminal youths. (She was afraid to report him; as it turned out, he was later killed by the police.) Further, one of those who wished to continue her education had earlier left school because her success as a student was attracting jealousy. ${ }^{30}$

29 It has become increasingly common throughout PNG for settlement dwellers to become alienated from village kin and village-based resources, such as access to land. Whether they thereby become 'lumpenproletariat' is interesting to contemplate.

30 Forsyth and Eves note that fear of sorcery, linked with jealousy and envy, leads 'to an unwillingness of some ... to work towards advancing their own living standards. Setting up businesses and becoming successful (especially if wealth is shown outwardly, such as in building new houses) is widely seen as being risky and as inviting a premature death through a sorcery attack' $(2015$, p. 11). 


\section{Schizmogenesis Among the Economically Precarious}

Clearly, many living at Sisiak were economically insecure. Many of those Chambri who did work in the formal economy (e.g. in the fish factory or as a security guard) were ill-paid if regularly employed. Some, as with labourers, were engaged in 'non-standard employment which is poorly paid, insecure, unprotected, and cannot support a household' (Munck, 2013, p. 758). Others, the majority, relied on the informal economy with small and uncertain market or roadside transactions. The Chambri experience at Sisiak appeared widespread in PNG:

Today, precarity characterises the experience of many urban Papua New Guineans, whether in formal employment or business, or earning a living through informal economic activities. For many Papua New Guineans, there is a disappointing gap between their aspirations for prosperity and their daily experiences of making a living. (Sharp et al., 2015)

As we have seen, that many Chambri living at Sisiak were short of cash forms only part of the story. Their economic precarity-and that of many other urban-dwelling Papuan New Guineans-was inflected by an ongoing ethos of competitive egalitarianism. Since developman at Sisiak never flourished and development had floundered, economic precarity ramified in a distinctive fashion. This precarity resulted in a moral economy of 'stingy' - if not downright mean-egalitarianism, one in which success was downplayed and appreciation, withheld.

Central to Sisiak's moral economy was jealousy—this, given and received by virtually everyone, had become a fact of social life. Jealousy was pervasive and made consequential due to ensuing sorcery and, to some extent, youth violence. The result was schizmogenesis, a negative feedback loop in which aspiration led to levelling, which then perpetuated precarity. ${ }^{31}$ John Taylor came to a similar conclusion concerning the 'deeply affective nature of sorcery'. Working with urban Vanutuans, he argued that the fear of sorcery 'exacerbates social and economic inequalities particularly as it contributes to the discouragement or advancement, especially among those already disempowered' (Taylor, 2015, p. 48).

31 See Taylor (2015) on the socially and psychologically pernicious effects of witchcraft. 
Conceivably, some collective action might eventually emerge at Sisiak from a common threat-perhaps of a mass eviction from government-owned land. ${ }^{32}$ Nevertheless, in the context of poverty inflected by jealousy and sorcery, it is difficult to imagine sustained community-building among Chambri, much less between them and their non-Chambri neighbours. ${ }^{33}$ While the Chambri and many of their Sisiak neighbours did suffer from precarity, they were neither solidary nor shared a consciousness of their condition. They did not, thus, constitute part of a social class of the precariat. Since jealousy at Sisiak seemed to feed (literally) on hunger, their best hope for the future might lie in a general easing of economic strictures. Still, this would seem outside their capacity to effect or compel.

Of course, those at Lihir also have little capacity to control their future economic circumstances, at least as these concern mining incomes. Certainly, the mining bonanza will pass and, with it, the capacity to achieve spectacular success of both developman and development. Correspondingly, ferocious egalitarianism, as a grand gesture of negative agency, may eventually lose its symbolic and practical feasibility. Yet, since not all their land has been subsumed by the mine, precarity may be forestalled. That said, for many Papua New Guineans living in cashbased, urban circumstances, the moral economy of places like Sisiak may increasingly prevail.

\section{References}

Bainton, N. \& Macintyre, M. (2013). 'My land, my work': Business development and large-scale mining in Papua New Guinea. In F. McCormack \& K. Barclay (Eds), Engaging with capitalism: Cases from Oceania (pp. 139-165). United Kingdom: Emerald Group Bingley.

Bainton N. \& Macintyre, M. (2016). Mortuary ritual and island riches in island Melanesia. In D. Lipset \& E. Silverman (Eds), Mortuary dialogues: Death ritual and the reproduction of moral community in Pacific communities (pp. 110-132). New York, NY: Berghahn.

Bashkow, I. (2006). The meaning of whitemen: Race and modernity in the Orokaiva cultural world. Chicago, IL: University of Chicago Press.

32 Michelle Rooney (2013) has documented a comparable eviction in Port Moresby.

33 But, for a more optimistic account of community members working together to address common problems, including those of crime, see Craig and Porter (2018). 
Bauman, R. (1975). Verbal art as performance. American Anthropologist, 77(2), 290-311.

Bourdieu, P. (1983). The field of cultural production. Cambridge, England: Cambridge University Press.

Carrier, J. (2017). Moral economy: What's in a name? Anthropological Theory, 18(1), 13-35.

Comaroff, J. \& Comaroff, J. (1991). Of revelation and revolution: Christianity, colonialism and consciousness in South Africa. Chicago, IL: University of Chicago Press.

Comaroff, J. \& Comaroff, J. (Eds). (2001). Millennial capitalism and the culture of neoliberalism. Durham, NC: Duke University Press.

Cox, J. (2018). Fast money schemes: Hope and deception in Papua New Guinea. Bloomington, IN: Indiana University Press.

Cox, J. \& Phillips, G. (2015). Sorcery, Christianity and the decline of medical services. In M. Forsyth \& R. Eves (Eds), Talking it through: Responses to sorcery and witchcraft beliefs and practices in Melanesia (pp. 37-54). Canberra, ACT: ANU Press. doi.org/10.22459/TIT.05.2015

Craig, D. \& Porter, D. (2018). Safety and security at the edges of the state: Local regulation in Papua New Guinea's urban settlements. Justice for the poor. Washington, DC: World Bank. Retrieved from documents.worldbank.org/ curated/en/184231530596208653/Safety-and-security-at-the-edges-of-thestate-local-regulation-in-Papua-New-Guinea-s-urban-settlements

Errington, F. K. \& Gewertz, D. (1987). Cultural alternatives and a feminist anthropology. Cambridge, England: Cambridge University Press.

Errington, F. K. \& Gewertz, D. (2005). On humiliation and class in contemporary Papua New Guinea. In J. Robbins \& H. Wardlow (Eds), The making of global and local modernities in Melanesia (pp. 163-170). Burlington, England: Ashgate.

Forsyth, M. \& Eves, R. (2015). The problems and victims of sorcery and witchcraft practices and beliefs in Melanesia: An introduction. In M. Forsyth \& R. Eves (Eds), Talking it through: Responses to sorcery and witchcraft beliefs and practices in Melanesia (pp. 1-19). Canberra, ACT: ANU Press. doi.org/ 10.22459/TIT.05.2015

Fortune, R. F. (1933). A note on some forms of kinship structures. Oceania, 4(1), $1-9$. 
Gesch, P. F. (2017). Varieties of local leadership in three peri-urban communities in Madang. Contemporary PNG Studies, 26, 109-120.

Gewertz, D. \& Errington, F. (1991). Twisted histories, altered contexts: Representing the Chambri in a world system. Cambridge, England: Cambridge University Press.

Gewertz, D. \& Errington, F. (2010). Cheap meat: Flap food nations in the Pacific Islands. Berkeley, CA: University of California Press.

Herriman, N. (2015). The morbid nexus: Reciprocity and sorcery in rural East Java. The Australian Journal of Anthropology, 26(2), 255-275.

Kirsch, S. (2006). Reverse anthropology. Stanford, CA: Stanford University Press.

Knauft, B. (1985). Good company and violence. Berkeley, CA: University of California Press.

Kulick, D. (1991). Law and order in Papua New Guinea. Anthropology Today, 7(5), 21-22.

Macintyre, M. (2008). Police and thieves, gunmen and drunks: Problems with men and problems with society in Papua New Guinea. The Australian Journal of Anthropology, 19(2), 179-193.

Maggio, R. (2018). 'According to kastom and according to law': 'Good life' and 'good death' in Gilbert Camp, Solomon Islands. In C. Gregory \& J. Altman (Eds), The quest for the good life in precarious times: Ethnographic perspectives on the domestic moral economy (pp. 57-86). Canberra, ACT: ANU Press. doi.org/ 10.22459/QGLPT.03.2018

Martin, K. (2013). The death of the big men and the rise of the big shots. New York, NY: Berghahan.

Mihalic, F. (1971). The Jacaranda dictionary and grammar of Melanesian Pidgin. Milton, Qld: The Jacaranda Press.

Munck, R. (2013). The precariat: A view from the South. Third World Quarterly, 34(5), 747-762.

Neilson, B. \& Rossiter, N. (2008). Precarity as a political concept, or, Fordism as exception. Theory, Culture and Society, 25(7-8), 51-72.

Oppermann, T. (2016). Coral roads and their sorcery: Lost authority and spectral commodification in Buka. Oceania, 86(2), 186-207. 
Rio, K. (2010). Handling sorcery in a state system of law: Magic, violence and kastom in Vanuatu. Oceania, 80(2), 182-197. doi.org/10.1002/j.1834-4461. 2010.tb00079.x

Robbins, J. \& Wardlow, H. (Eds). (2005). The making of global and local modernities in Melanesia: Humiliation, transformation and the nature of cultural change. Burlington, England: Ashgate.

Rooney, M. (2013, 5 April). Another Port Moresby community bulldozed. Retrieved from www.devpolicy.org/another-port-moresby-community-bull dozed-2013040/

Russell D. Taylor and Partners Pty Ltd. (1972). Madang urban study. Konedobu: Department of Lands, Surveys and Mines.

Sahlins, M. (1992). The economics of develop-man in the Pacific. Res: Anthropology and Aesthetics, 21, 12-25.

Schwoerer, T. (2017). Sorcery and warfare in the Eastern Highlands of Papua New Guinea. Oceania, 87(3), 317-336.

Sharp, T., Cox, J., Spark. C., Lusby, S. \& Rooney, M. (2015). The formal, the informal and the precarious: Making a living in Papua New Guinea. Retrieved from dpa.bellschool.anu.edu.au/experts-publications/publications/1292/formalinformal-and-precarious-making-living-urban-papua-new

Sinclair, J. (2006). Madang. Madang, Papua New Guinea: Divine Word University Press.

Smith, J. \& Mwadime, N. (2015). Email from Ngeti: An ethnography of sorcery, redemption and friendship in global Africa. Berkeley, CA: University of California Press.

Taylor, J. (2015). Sorcery and the moral economy of agency: An ethnographic account. Oceania, 85(1), 38-50.

Tonkinson, R. (1981). Sorcery and social change in southeast Ambrym, Vanuatu. Social Analysis: The International Journal of Social and Cultural Practice, 8, 77-88.

Wardlow, H. (2006). Wayward women: Sexuality and agency in a New Guinea society. Berkeley: University of California Press. 
This text is taken from Unequal Lives: Gender, Race and Class in the Western Pacific, edited by Nicholas A. Bainton, Debra McDougall, Kalissa Alexeyeff and John Cox, published 2021 by ANU Press, The Australian National University, Canberra, Australia.

doi.org/10.22459/UE.2020.08 